\title{
PENINGKATAN KEMAMPUAN MEMBACA INTENSIF DENGAN MENGGUNAKAN METODE KWL DI KELAS X SMAN 10 PONTIANAK
}

\author{
Dian Apendiani \\ SMA Negeri 10 Pontianak \\ Email:dianapendiani@gmail.com
}

\begin{abstract}
Abstrak
Kemampuan membaca intensif siswa SMA Negeri 10 masih belum memenuhi harapan. Penelitian ini secara umum bertujuan untuk mengetahui pengaruh penggunaan metode KWL terhadap kemampuan membaca intensif dan minat baca siswa kelas X SMA Negeri 10 Pontianak. Penelitian ini merupakan penelitian tindakan kelas yang terdiri atas dua siklus dan dilaksanakan di SMAN 10 pada kelas XD semester ganjil. Penelitian dilakukan pada 38 orang siswa yang terdiri atas 19 siswa perempuan dan 19 siswa laki-laki. Data hasil pengamatan dianalisis secara deskriptif. Sedangkan data hasil kuesioner dianalisis secara kuantitatif. Hasil penelitian ini diantaranya 1) Pembelajaran membaca dengan menggunakan metode KWL dapat digunakan dengan merancang pembelajaran dalam tiga tahap. 2) Pembelajaran membaca dengan metode KWL dapat meningkatkan kemampuan membaca pemahaman pada siswa kelas X SMA Negeri Pontianak ditunjukan oleh hasil evaluasi yaitu sebanyak $81,57 \%$ siswa dapat memahami wacana dengan baik dan sisanya ada pada kriteria cukup, dan 3) Metode KWL dapat meningkatkan minat baca siswa kelas X SMA Negri 10 Pontianak dan sebanyak 35 siswa $(92,10 \%)$ menyatakan bahwa metode KWL mempermudah siswa dalam memahami wacana dan mendorong mereka untuk membaca dan mencari informasi lebih lanjut mengenai tema yang terkait.
\end{abstract}

\section{Kata Kunci: Kemampuan Membaca Intensif, Metode KWL}

\section{PENDAHULUAN}

Pembelajaran bahasa Indonesia diarahkan untuk meningkatkan kemampuan peserta didik dalam berkomunikasi menggunakan bahasa Indonesia dengan baik dan benar, baik secara lisan maupun tulis. Untuk dapat berkomunikasi dengan baik, maka kemampuan berkomunikasi harus dilatih melalui belajar. Kemampuan berkomunikasi erat kaitannya dengan empat ranah keterampilan berbahasa yang perlu dikembangkan, yaitu keterampilan mendengarkan, berbicara, membaca, dan menulis.

Membaca merupakan bagian terpadu dari kemampuan berbahasa. Membaca sangat bersandar pada kemampuan berbahasa. Pendekatan pengalaman berbahasa dapat digunakan dalam pengajaran membaca. Menurut pendekatan ini, kekuatan konseptual dan linguistik yang dibawa peserta didik ke sekolah harus digunakan secara penuh.
Keterampilan membaca merupakan modal utama bagi peserta didik dalam belajar. Mereka dapat mengkomunikasikan gagasan dan mengekspresikan dirinya melalui lisan dan tulisan mengenai hal-hal yang dipelajarinya dalam membaca. Oleh kerena itu, kegagalan dalam penguasaan keterampilan ini akan mengakibatkan masalah dalam belajar.

Pembelajaran membaca pada tingkat SMA, mencakup membaca intensif. Membaca intensif adalah kemampuan memahami detail secara akurat, lengkap, dan kritis terhadap fakta, konsep, gagasan, pendapat, pengalaman, pesan, dan perasaan yang ada pada wacana tulis (http://starbringbrightsight.multiply.com/notes/it $\mathrm{em} / 1$ ). Kemampuan membaca intensif diperlukan oleh siswa pada saat pembelajaran Kompetensi Dasar membaca melayu klasik, membaca paragraf deduktif induktif, membaca artikel, membaca unsure intrinsik. Kemampuan 
membaca intensif pada tingkat SMA sangat penting karena kemampuan ini menjadi bekal peserta didik dalam mempelajari berbagai pengetahuan secara kritis.

Pada kenyataannya di lapangan, kemampuan membaca intensif siswa SMA negeri 10 , tempat penulis mengajar, masih belum memenuhi harapan. Ini didasarkan pada studi pendahuluan yang dilakukan penulis dan berdasarkan hasil pengamatan penulis selama mengajar. Studi pendahuluan dilakukan terhadap kelas XD, dengan hasil rata-rata kemampuan membaca intensif siswa sebesar $36,84 \%$. Dari hasil analisis terhadap tes yang dilakukan penulis terhadap siswa kelas XD, penulis mendapat gambaran bahwa kemampuan membaca intensif pada siswa kelas X masih perlu ditingkatkan.

Ada sinyalemen bahwa rendahnya kemampuan membaca tersebut dapat disebabkan beberapa faktor. Faktor tersebut diantaranya adalah kurangnya minat baca, minimnya sarana dan prasarana, dan metode pembelajaran membaca yang kurang menarik.

Minat merupakan salah satu disposisi (kecenderungan) individu yang berdasar pada kesenangan dan hasrat yang selalu timbul untuk memiliki atau melakukan sesuatu. Minat seseorang menimbukan motivasi untuk mendapatkan atau melakukan apa yang diminatinya. Besar atau kecilnya minat yang ada dalam dirinya terhadap sesuatu berpengaruh pada kuat atau lemahnya motivasi yang dimilikinya. Dengan demikian, minat baca seorang siswa akan mempengaruhi motivasinya untuk membaca. Begitu juga dengan siswa SMA 10, kemampuan dan kebiasaan membaca mereka masih perlu ditingkatkan. Penulis jarang mendapatkan siswa yang di sela waktu istirahatnya dimanfaatkan untuk membaca buku. Sebaliknya penulis mengamati bahwa siswa cenderung asyik menggunakan HP di saat ada waktu senggang.

Isu tentang kurangnya minat baca anakanak bukanlah sesuatu yang perlu dipertanyakan lagi. Bahkan, bukan hanya anak-anak yang minatnya terhadap buku bisa dibilang hampir tidak ada, remaja dan orang dewasa pun, kalau diperhatikan, jarang sekali berkeliling dengan hidung terbenam di sela halaman sebuah buku. Kesimpulan ini di dukung oleh penelitian yang dilakukan oleh hasil Programme for International Student Assessment (PISA) 2012 yang menunjukkan bahwa dari 65 negara anggota PISA, pendidikan Indonesia berada di bawah peringkat 64. Menurut PISA, tingkat membaca pelajar Indonesia menempati urutan ke-64 dari 65 negara anggota PISA. Indonesia hanya mengumpulkan skor membaca 375 poin. Tingkat membaca penduduk Indonesia tertinggal dari negara tetangga, Thailand (50) dan Malaysia (52) (www.indonesiapisacenter.com). Ini menunjukkan bahwa persentase baca anak-anak Indonesia benar-benar rendah.

Kemampuan membaca juga dipengaruhi oleh kurangnya sarana dan prasarana. Kita dapat melihat dengan jelas bahwa perpustakaan, baik perpustakaan daerah maupun perpustakaan yang ada di sekolah, khususnya di SMA negeri 10 , kurang diminati siswa. Hal ini disebabkan oleh sarana perpustakaan yang sangat minim. Kalau kita lihat sarana perpustakaan di SMA 10, kita akan melihat bahwa perpustakaan ini sangat tidak memadai. Hal ini disebabkan karena SMA 10 adalah SMA yang baru, sehingga sarana perpustakaan belum tergarap. Begitu juga, dari segi pengadaan buku-bukunya. Buku-buku yang ada di perpustakaan, selain masih sangat sedikit, juga dari segi jenis atau genre, masih sangat minim. Keadaan ini mempengaruhi minat membaca siswa, karena siswa menjadi tidak bergairah untuk pergi ke perpustakaan di sela waktu senggangnya. Minat baca siswa yang rendah ini ujung-ujungnya akan mempengaruhi kemampuan siswa dalam membaca.

Pembelajaran bahasa Indonesia diarahkan untuk meningkatkan kemampuan peserta didik untuk berkomunikasi dalam bahasa Indonesia dengan baik dan benar, baik secara lisan maupun tulis, serta menumbuhkan apresiasi terhadap hasil karya kesastraan Indonesia (KTSP 2006:260). Melalui komunikasi siswa dapat mengungkapkan gagasan, ide, dan pendapatnya tentang sesuatu kepada orang lain. Untuk dapat berkomunikasi dengan baik, maka kemampuan berkomunikasi harus dilatih melalui belajar. Tugas guru adalah memberikan pengalaman berbahasa secara langsung kepada siswa. Guru juga dapat mengembangkan kompetensi bahasa peserta didik dengan menyediakan berbagai kegiatan berbahasa, sumber belajar, bahan ajar, metode, dan media yang disesuaikan dengan kondisi lingkungan sekolah dan kemampuan peserta didik.

Untuk dapat meningkatkan keterampilan berbahasa yang optimal, guru bahasa Indonesia harus mampu memilih metode yang paling tepat sesuai dengan kondisi siswa. Metode pengajaran 
membaca yang kurang menarik akan membuat kemampuan membaca siswa kurang terasah. Banyak metode yang digunakan guru dalam pembelajaran membaca, diantaranya adalah metode tradisional. Nampaknya metode inilah yang sering kali digunakan oleh guru bahasa Indonesia di SMAN 10. Metode ini dimulai dari siswa diminta membaca sebuah wacana, kemudian mereka menjawab pertanyaan sesuai isi wacana. Metode ini digunakan oleh guru, mulai dari guru SD sampai SMA. Metode lain dalam pembelajaran membaca diantaranya adalah metode KWL.

Dengan metode KWL, diharapkan pembelajaran membaca lebih menarik. Selain itu, metode KWL (What I Know, What I Want to know, What I have Learned) merupakan strategi membaca yang berbasis keaktifan siswa. Dalam metode ini terdapat tiga langkah dasar yaitu mengingat apa yang telah diketahui, menentukan apa yang ingin mereka ketahui, dan mengingat apa yang mereka pelajari dari membaca. Dengan penerapan metode KWL diharapkan siswa akan lebih mampu mengeksplor pengetahuan dan menjadikannya pembaca yang kritis.

Dari gambaran di atas, penulis merasa tertarik untuk meneliti kemampuan membaca siswa yang menggunakan metode KWL dan apa pengaruhnya terhadap minat baca siswa.

\section{METODE}

Penelitian ini merupakan penelitian tindakan kelas yang dilaksanakan di SMAN 10 pada kelas XD semester ganjil. Penelitian dilakukan pada 38 orang siswa yang terdiri atas 19 siswa perempuan dan 19 siswa laki-laki. Prosedur PTK ini terdiri dari dua siklus, tiap siklus dilaksanakan sesuai dengan perubahan yang ingin dicapai seperti yang telah didesain dalam rencana yang ingin diteliti. Data yang diperoleh pada penelitian ini menggunakan observasi langsung dan kuisioner. Data yang terkumpul dianalisis secara kualitatif dan kuantitatif. Data hasil pengamatan dianalisis secara deskriptif. Sedangkan data hasil kuesioner dianalisis secara kuantitatif.

\section{HASIL DAN PEMBAHASAN}

\section{A. Siklus Pertama}

\section{Perencanaan}

Dalam tahap ini, peneliti melakukan kegiatan-kegiatan sebagai berikut.

a. Pembuatan Skenario Pembelajaran
Skenario pembelajaran dibuat dalam format RPP (Rencana Pelaksanaan pembelajaran) baku yang berlaku di SMAN 10.

b. Pembuatan LKS (Lembar Kerja siswa)

LKS dibuat langkah demi langkah untuk memandu siswa dalam melaksanakan pembelajaran membaca menggunakan metode KWL.

c. Pembuatan Lembar Observasi

Lembar observasi yang dibuat terdiri dari lembar observasi siswa yang bertujuan mengukur tingkat keaktifan dan minat siswa serta lembar observasi guru yang bertujuan untuk mengukur pelaksanaan skenario pembelajaran.

d. Pembuatan Kartu KWL

Pembuatan kartu KWL terdiri dari tiga kolom. Kolom K, kolom W, kolom L.

2. Pelaksanaan

Dalam tahap pelaksanaan, skenario pembelajaran dapat terlaksana dengan lancar. Pada kegiatan awal, guru melakukan apersepsi untuk memotivasi siswa bahwa membaca merupakan kegiatan yang dapat membuka wawasan. Dalam kesempatan tersebut, guru juga menjelaskan tujuan pembelajaran.

Kegiatan inti dimulai dengan penjelasan metode KWL, kemudian guru membagikan kartu KWL. Siswa diminta menuliskan hal-hal yang mereka ketahui tentang tema yang sudah disiapkan oleh guru pada kolom K. Hal ini bertujuan untuk mempersiapkan siswa secara mental dan mengeksplorasi pengalaman belajar siswa mengenai tema yangsudah ditentukan sebelumnya. Setelah siswa menuliskan hal-hal yang mereka ketahui dalam kolom $\mathrm{K}$, siswa diminta menuliskan hal-hal yang ingin mereka ketahui dalam kolom W. Hal ini bertujuan untuk mengembangkan pertanyaan terhadap topik dan dapat dijadikan pedoman dalam menilai hasil membaca. Setelah kolom K dan W diisi, guru membagikan lembar wacana sesuai tema untuk dibaca oleh siswa. Selesai membaca, lembar wacana dikumpulkan 
kemudian siswa diminta untuk menuliskan hal-hal yang mereka pelajari pada kolom L. Selama kegiatan di atas, guru terus memonitor aktivitas siswa dan memberikan bimbingan pada siswa yang mengalami kesulitan.

Pada tahap berikutnya, guru memberikan evaluasi. Evaluasi ini bertujuan untuk mengetahui tingkat pemahaman siswa terhadap wacana yang telah dibaca. Siswa menjawab beberapa pertanyaan berkaitan dengan hal-hal yang sudah mereka baca.

Tahap pelaksanaan dapat dilihat dalam skenario pembelajaran berikut.

Tabel 1. Skenario Pembelajaran

\begin{tabular}{|c|c|c|}
\hline No. & Kegiatan Belajar & $\begin{array}{l}\text { Nilai Budaya Dan } \\
\text { Karakter Bangsa }\end{array}$ \\
\hline 1. & $\begin{array}{l}\text { Kegiatan Awal : } \\
\text { - Guru menjelaskan Tujuan Pembelajaran hari ini. } \\
\text { - Guru melakukan apersepsi dengan cara mendeskripsikan } \\
\text { berbagai pengalaman membaca. }\end{array}$ & $\begin{array}{l}\text { Bersahabat/ } \\
\text { komunikatif }\end{array}$ \\
\hline 2. & $\begin{array}{l}\text { Kegiatan Inti : } \\
\text { - Siswa mendapat penjelasan tentang metode membaca dengan } \\
\text { menggunakan kartu KWL } \\
\text { - Siswa mendapatkan kartu KWL yang dibagikan oleh guru } \\
\text { - Siswa diberi satu tema bahasan. } \\
\text { - Siswa mengisi kolom K dengan hal-hal yang mereka ketahui } \\
\text { tentang tema bahasan. } \\
\text { - Siswa menuliskan hal-hal yang ingin mereka ketahui mengenai } \\
\text { tema bahasan dalam kolom W. } \\
\text { - Guru membagikan wacana sesuai tema bahasan. } \\
\text { - Siswa membaca wacana. } \\
\text { - Siswa bersama guru menggali hal-hal yang didapatkan dari } \\
\text { wacana. } \\
\text { - Siswa menuliskan hal-hal yang mereka dapatkan dalam kolom } \\
\text { L. } \\
\text { - Siswa menjawab pertanyaan berhubungan dengan wacana } \\
\text { - Siswa dan guru bersama -sama menggali hal-hal yang tidak ada } \\
\text { di dalam wacana. } \\
\text { - Siswa menceritakan kembali isi wacana dengan kata-kata } \\
\text { sendiri. }\end{array}$ & Tanggung jawab \\
\hline 3. & $\begin{array}{l}\text { Kegiatan Akhir : } \\
\text { - } \text { Refleksi } \\
\text { - } \text { Guru dan siswa menyimpulkan pembelajaran hari ini. } \\
\text { - }\end{array}$ & $\begin{array}{l}\text { Bersahabat/ } \\
\text { komunikatif }\end{array}$ \\
\hline
\end{tabular}

3. Pengamatan

Dalam kegiatan pengamatan, guru mengamati secara langsung keaktifan siswa dan minat siswa terhadap wacana. Di samping mengamati perilaku belajar siswa, guru juga mengadakan penilaian terhadap kemampuan pemahaman siswa terhadap wacana.
Berdasarkan

pengamatan langsung, terlihat bahwa terjadi proses eksplorasi pengetahuan dan pengalaman belajar siswa sebelum kegiatan membaca. Kegiatan ini membuat siswa aktif berusaha mengingat kembali pengetahuan yang sudah diperoleh sebelumnya. Begitu pula dalam proses selanjutnya, siswa terlihat aktif untuk 
menggali berbagai pertanyaan yang berkaitan dengan tema wacana.

Pada tahap ini terlihat bahwa masih ada beberapa siswa yang mengalami kesulitan dalam menuliskan hal-hal yang harus mereka tulis pada kolom $\mathrm{K}$ dan kolom W. Kegiatan menulis pada kolom L mengenai hal-hal yang mereka pelajari setelah membaca, terlihat lebih lancar. Berdasarkan pengamatan menggunakan lembar observasi, terdapat 4 orang siswa yang merasakan kesulitan untuk mengisi kolom $\mathrm{K}$ dan $\mathrm{W}$.

Hasil penilaian terhadap pemahaman bacaan menunjukkan bahwa sebanyak 68,42 \% (26 orang) menunjukan nilai baik, sedangkan sisanya sebanyak 31,57\% (12 orang) menunjukan nilai cukup.

4. Refleksi

Pada tahap ini, hasil pengamatan dan penilaian selama berlangsungnya proses pembelajaran dikumpulkan dan dianalisis. Kemampuan membaca pemahaman siswa setelah dilakukan pembelajaran membaca pemahaman dengan menggunakan metode KWL jika dibandingkan dengan tes awal, dapat digambarkan sebagai berikut.

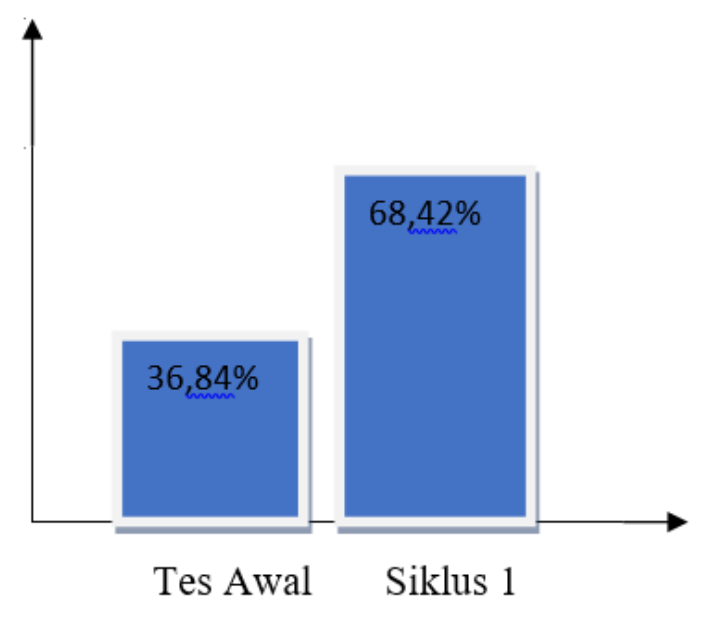

\section{Grafik 1. Kemampuan Membaca Siswa}

Grafik di atas menunjukkan pada siklus pertama terdapat $68,42 \%$ atau sebanyak 26 siswa yang menunjukkan kemampuan pemahaman membaca teks yang dikatagorikan baik dan sangat baik. Sedangkan sebanyak $31,57 \%$ belum mencapai kriteria minimal.

Dari hasil pengamatan dan penilaian dapat diketahui bahwa dalam pembelajaran membaca pemahaman dengan menggunaan metode KWL terdapat dukungan dan hambatan. Adapun dukungan kelebihan penggunaan metode KWL dalam pembelajaran membaca pemahaman adalah sebagai berikut.

a. Siswa dapat mempersiapkan mental dan mengeksplorasi pengalaman belajar sebelumnya guna membangun pengetahuan terkait tema.

b. Siswa dapat menggali berbagai pertanyaan berkaitan dengan tema. Hal ini memunculkan rasa penasaran yang diharapkan dapat meningkatkan minat baca.

c. Proses membaca yang merupakan proses komunikasi pasif berubah menjadi proses yang aktif.

Sedangkan hambatan atau kelemahan yang dialami dalam proses pembelajaran membaca dengan menggunakan metode KWL adalah sebagai berikut.

a. Siswa belum terbiasa menggali pengalaman belajar terkait tema yang sudah ditentukan. 
b. Siswa belum terbiasa menggali pertanyaan terkait tema yang sudah ditentukan.

c. Beberapa siswa kurang tertarik dengan tema yang dipilihkan oleh guru.

d. Kelemahan pada (a) dan (b) merupakan akibat dari belum terbiasanya siswa menggunakan metode KWL dalam pembelajaran membaca.

Untuk mengatasi masalah tersebut, pada siklus dua akan ditempuh beberapa cara, antara lain:

a. Guru memberikan contoh konkret cara menuliskan hal-hal yang terkait pengalaman belajar yang harus ditulis pada kolom $\mathrm{K}$.

b. Guru memberikan contoh konkret cara menggali pertanyaan dan menuliskannya pada kolom W. c. Guru mencari tema bacaan yang sesuai dengan minat siswa ditambah dengan penggunaan gambar sesuai dengan tema.

\section{B. Siklus Kedua}

\section{Perencanaan}

Pada siklus kedua ini, diharapkan siswa lebih terkondisi dalam menggunakan metode KWL. Rencana pada siklus kedua ini sama dengan perencanaan pada siklus pertama. Hanya pada saat pembuatan LKS, guru mencari tema bacaan yang sesuai dengan usia dan minat siswa. Agar lebih menarik, ditambahkan gambar yang berkaitan dengan tema. Penambahan gambar diharapkan memberikan stimulus yang dapat membangkitkan pengalaman belajar siswa.

Skenario pembelajaran pada siklus 2 adalah sebagai berikut.

Tabel 1. Skenario Pembelajaran

\begin{tabular}{|c|c|c|}
\hline No. & Kegiatan Belajar & $\begin{array}{c}\text { Nilai Budaya Dan } \\
\text { Karakter Bangsa }\end{array}$ \\
\hline 1. & $\begin{array}{l}\text { Kegiatan Awal : } \\
\text { - Siswa berdoa bersama } \\
\text { - Guru menjelaskan Tujuan Pembelajaran hari ini. } \\
\text { - Guru melakukan apersepsi dengan cara mendeskripsikan } \\
\quad \text { berbagai pengalaman membaca. }\end{array}$ & $\begin{array}{l}\text { Bersahabat/ } \\
\text { komunikatif }\end{array}$ \\
\hline 2. & $\begin{array}{l}\text { Kegiatan Inti : } \\
\text { - Siswa mendapat penjelasan tentang metode membaca dengan } \\
\text { menggunakan kartu KWL } \\
\text { - Siswa mendapatkan kartu KWL yang dibagikan oleh guru } \\
\text { - Siswa diberi satu tema bahasan. } \\
\text { - Siswa mengisi kolom K dengan hal-hal yang mereka ketahui } \\
\text { tentang tema bahasan. } \\
\text { - Siswa menuliskan hal-hal yang ingin mereka ketahui mengenai } \\
\text { tema bahasan dalam kolom W. } \\
\text { - Guru membagikan wacana sesuai tema bahasan. } \\
\text { - Siswa membaca wacana. } \\
\text { - Siswa bersama guru menggali hal-hal yang didapatkan dari } \\
\text { wacana. } \\
\text { - Siswa menuliskan hal-hal yang mereka dapatkan dalam kolom } \\
\text { L. } \\
\text { - Siswa menjawab pertanyaan berhubungan dengan wacana } \\
\text { - Siswa dan guru bersama -sama menggali hal-hal yang tidak ada } \\
\text { di dalam wacana. } \\
\text { - Siswa menceritakan kembali isi wacana dengan kata-kata } \\
\text { sendiri. }\end{array}$ & Tanggung jawab \\
\hline
\end{tabular}



3. Kegiatan Akhir :
Bersahabat/
- Refleksi
komunikatif
- Guru dan siswa menyimpulkan pembelajaran hari ini.
- Penugasan.

2. Pelaksanaan

Pelaksanaan pembelajaran pada siklus kedua berjalan dengan baik. Setelah membuka pelajaran dengan apersepsi dan memberitahukan tujuan pembelajaran, guru membagikan kartu KWL. Guru menjelaskan cara menggunakan kartu KWL disertai contoh kokret cara penulisannya, baik pada kolom K, kolom W, maupun kolom L.

Berikutnya, guru menyampaikan tema bacaan dan memperlihatkan gambar sesuai dengan tema bacaan. Kemudian siswa menuliskan pengetahuan dan pegalaman belajarnya terkait tema. Langkah berikutnya, siswa menuliskan hal-hal yang ingin mereka ketahui terkait dengan tema. Selanjutnya guru membagikan LKS yang di dalamnya terdapat wacana terkait tema yang sudah ditentukan terlebih dahulu. Setelah siswa membaca, siswa menuliskan hal-hal yang mereka pelajari dari bacaan yang sudah mereka baca.

Selama proses pembelajaran di atas, guru melakukan pengamatan dan bimbingan bagi siswa yang mendapat kesulitan. Evaluasi dilakukan pada tahap akhir untuk mengetahui tingkat pemahaman siswa terhadap bacaan.

3. Pengamatan

Pembelajaran membaca menggunakan metode KWL pada siklus kedua terlihat lebih terkondisi. Siswa terlihat lebih aktif dan minat siswa terhadap bacaan lebih terlihat. Beberapa siswa yang pada siklus pertama mengalami kesulitan, sudah dapat mengatasi kesulitannya. Nampaknya penggunaan gambar yang terkait tema dapat memicu minat dan memotivasi siswa untuk mengingat kembali pengalaman belajarnya.

Hasil penilaian pemahaman terhadap bacaan menghasilkan data sebagai berikut. Sebanyak 31 atau sebanyak $81,57 \%$ siswa menunjukan nilai baik dan sangat baik dan sisanya sebanyak 7 atau sebanyak 18,42\% siswa menunjukan nilai cukup.

4. Refleksi

Pelaksanaan pembelajaran membaca pemahaman dengan menggunakan metode KWL pada siklus 2 ini dapat digambarkan sebagai berikut.

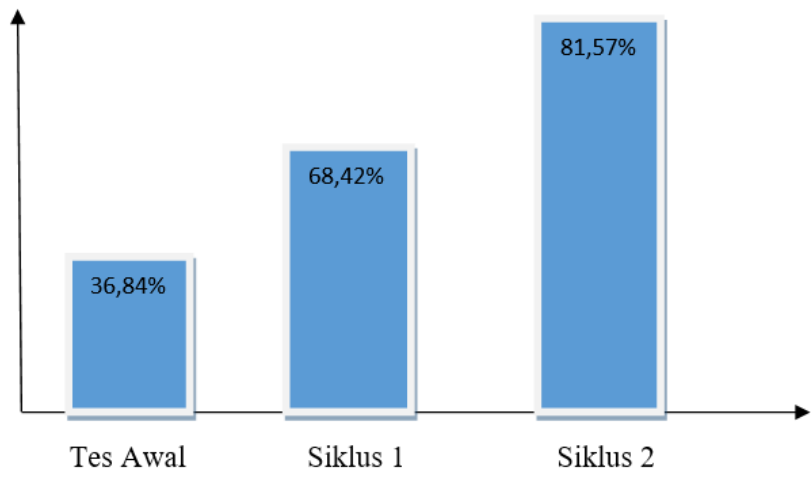

Grafik 2. Hasil Pelaksanaan Pembelajaran Metodde KWL

Pelaksanaan pembelajaran berjalan dengan baik dan lancar karena siswa sudah terkondisi dengan penggunaan metode KWL. Terjadi peningkatan pemahaman membaca yang cukup signifikan setelah diasakan perbaikan pembelajaran dari siklus pertama. Pemberian contoh konkret dalam penulisan kartu KWL mempermudah siswa dalam 
memahami penggunaan kartu KWL. Pemilihan tema berpengaruh pada minat siswa dalam membaca. Tema yang sesuai dengan usia dan minat siswa, membuat pembelajaran lebih dinamis. Penambahan gambar yang sesuai dengan tema, nampaknya dapat memotivasi dan memicu minat siswa dalam memperoleh pengalaman membaca.

\section{KESIMPULAN DAN SARAN \\ Kesimpulan}

Berdasarkan hasil penelitian terhadap siswa kelas XD, SMAN 10, maka dapat disimpulkan hal-hal sebagai berikut:

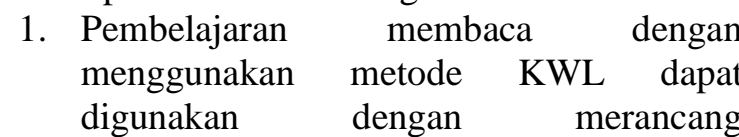
pembelajaran dalam tiga tahap. Tahap pertama adalah mempersiapkan siswa sebelum kegiatan membaca, tahap kedua membimbing siswa untuk menentukan tujuan membaca, tahap ketiga merupakan tindak lanjut untuk menemukan dan memperluas pengetahuan siswa.

2. Pembelajaran membaca dengan metode KWL dapat meningkatkan kemampuan membaca pemahaman pada siswa kelas $\mathrm{X}$ SMA Negeri Pontianak. Hal ini ditunjukan oleh hasil evaluasi yaitu sebanyak $81,57 \%$ siswa dapat memahami wacana dengan baik. Sisanya ada pada kriteria cukup.

3. Metode KWL dapat meningkatkan minat baca siswa kelas X SMA Negri 10 Pontianak. Minat baca ini dapat dilihat dari hasil pengamatan terhadap proses pembelajaran yang berlangsung dinamis dan dari hasil lembar observasi. Lembar observasi menunjukkan bahwa sebanyak 35 siswa $(92,10 \%)$ menyatakan bahwa metode KWL mempermudah siswa dalam memahami wacana dan mendorong mereka untuk membaca dan mencari informasi lebih lanjut mengenai tema yang terkait.

Saran

1. Saran untuk Siswa

Membaca merupakan kunci untuk memahami berbagai pengetahuan. Penggunaan metode KWL dalam membaca, terbukti dapat meningkatkan kemampuan membaca pemahaman. Untuk itu, disarankan siswa menggunakan metode dan kartu KWL bukan hanya pada pelajaran bahasa Indonesia, tetapi juga pada pelajaran lain.

2. Saran untuk Guru

Para guru bahasa Indonesia, pada umumnya belum mengenal metode KWL dalam pembelajaran membaca. Metode ini merupakan alternatif lain dalam proses pembelajaran membaca pemahaman karena terbukti bahwa metode ini dapat meningkatkan dinamika pembelajaran dan meningkatkan pemahaman terhadap bacaan.

3. Bukan hanya guru bahasa Indonesia saja yang dapat menerapkan metode ini, guru bidang studi lain pun diharapkan dapat menggunakan metode KWL agar siswa dapat lebih menggali pengetahuan dan pengalaman belajarnya.

\section{DAFTAR RUJUKAN}

Depdiknas. 2006. Kurikulum Tingkat satuan Pendidikan (KTSP) untuk Sekolah Dasar/ MI. Jakarta: Terbitan Depdiknas.

OECD. 2012. PISA 2009 Technical Report. PISA: OECD Publishing.

http://starbringbrightsight.multiply.com/notes/i tem/1. Diakses 4 Mei 2018.

www.indonesiapisacenter.com. Diakses 4 Mei 2018 . 